\title{
Preparation and Characterization of Citrus Aurantifolia Lime Oils Microcapsules by Complex Coacervation Technique
}

\author{
EUIS JULAEHA ${ }^{1}$, MOHAMAD NURZAMAN ${ }^{2}$, DIANA RAKHMAWATY EDDY ${ }^{1}$, \\ DIKDIK KURNIA ${ }^{1}$, SANDRA PUSPITA ${ }^{1}$, YUDI ROSANDI ${ }^{3}$, TATANG WAHYUDI ${ }^{4}$, \\ JAMALUDIN AL ANSHORI. ${ }^{*}$ \\ ${ }^{1}$ Department of Chemistry, Faculty of Mathematics and Natural Sciences, Universitas Padjadjaran, Jl. Raya Bandung - \\ Sumedang km.21, Jatinangor Sumedang 45361 West Java, Indonesia \\ ${ }^{2}$ Department of Biology, Faculty of Mathematics and Natural Sciences, Universitas Padjadjaran, Jl. Raya Bandung - \\ Sumedang km.21, Jatinangor Sumedang 45361 West Java, Indonesia \\ ${ }^{3}$ Department of Geophysics, Faculty of Mathematics and Natural Sciences, Universitas Padjadjaran, Jl. Raya Bandung - \\ Sumedang km.21, Jatinangor Sumedang 45361 West Java, Indonesia \\ ${ }^{4}$ Center for Textile, Bandung, West Java, Indonesia
}

Abstract: The Lime oil of Citrus aurantifolia was microencapsulated by coacervation technique employing gelatine and alginates as the shells, and calcium chloride as cross linker. Optimization of core/shell ratio, speed and temperature of stirring was carried out. Structure and shape of the microcapsules were characterized by particle size analyzer (PSA) and scanning electron microscope (SEM) respectively. The properties of microcapsules such as, yield, particle size distribution, oil content, oil load, and encapsulation efficiency were also determined. Upon condition of ratio core/shell 0.49, speed and temperature of stirring at $600 \mathrm{rpm}$ and $35^{\circ} \mathrm{C}$ respectively, the microcapsules of LOs with improved performance were achieved with efficiency of $46 \%$ and oil content of $78 \%$.

Keywords: microencapsulation, complex coacervation, lime oil, Citrus aurantifolia

\section{Introduction}

Encapsulation is a technique of enclosing droplets or small particles of a sensitive substance (called core) within a continuous thin film of polymer shell. Thus, the core is protected from the effects of environmental changes and retarded from being released $[1,2]$. Microencapsulation can be carried out by several methods, such as phase separation, phase change polymerization of materials in situ, mini emulsion polymerization, coacervation, or solvent evaporation [3] while considering some essential factors including: coating material and capsule core, core/shell ratio, viscosity, type of solvent, addition of additives [4]. In addition, it also requires such careful control of temperature, time, speed of stirring $[5,6], p \mathrm{H}$, and others [7].

Citrus aurantifolia essential oil (LOs) has been increasingly utilized for various needs in everyday life, including for: cosmetics, health, cleaning, dentistry, antiseptics, perfumes, insect repellents, adhesives, and flavor since it has substantial amounts of beneficial compounds of terpene secondary metabolites (monoterpenes and sesquiterpenes both oxygenated and non-oxygenated), alcohols, esters, ethers, lactones, ketones, phenols, and hydrocarbons [8,9]. Thus, it exhibits various activities, such as antimicrobial, repellent, astringent, anthelmintic, diuretic, antiviral, antiseptic [10], antioxidants [11], and insecticides [12]. However, the oil is chemically unstable and susceptible to oxidative deterioration, especially when exposed to light, changes in moisture and temperature, and oxygen in the air [13-16]. Therefore, microencapsulation technique is employed to suppress or retard oxidation process and increase a range of applications in the health, commercial, textile, agriculture, and other fields [14].

In term of fairly simple process of microencapsulation at ambient temperatures, and high loading capacity of oil core [17], complex coacervation method has been utilized frequently. The method employs one or more charged coating polymers which combine proteins and polymers such as Arabic protein soybean [13, 18], gelatine-gum Arabic [1], and alginate-gelatine [19]. Microencapsulation of

\footnotetext{
*email: jamaludin.al.anshori@unpad.ac.id
} 
various essential oils with such method with charged coating polymers of alginate-gelatine have been reported for clove oil [20], olive oil [19], and ginger oil [7]. However, to the best of author's knowledge none of data reported the encapsulation of LOs by those biopolymers, apart of applying double coating of konjac glucomannan and gum Arabic [21], gum acacia and gelatine [22], and chitosan and gum arabic [23].

The main objective of this paper was to prepare and characterize microcapsules of C. aurantifolia essential oil (LOs) coated by two biopolymers of gelatine and sodium alginate for improved LOs microcapsules performance, and thus, be extensively applied in daily needs of live.

\section{Materials and methods}

\subsection{Materials}

Analytical grade of anhydrous sodium sulfate and glacial acetic acid was supplied by Merck, while technical grade of Tween 80, gelatine, alginate, calcium chloride, and $n$-hexane were purchased at local chemical store and used without further purification. Lime oils (LOs) were obtained from C. aurantifolia peels by hydrodistillation.

\subsection{Preparation of Lime Oil (LOs)}

Preparation of LOs was based on a literature procedure [24]. The peels of $C$. aurantifolia separated from the fruit were washed thoroughly with running tap water and cut into small pieces. The peels were then distilled using hydrodistillation technique at $100^{\circ} \mathrm{C}$ for $3 \mathrm{~h}$. The LOs was separated from water, dried over anhydrous sodium sulfate, and stored at $5^{\circ} \mathrm{C}$ in a sealed vial. The procedure was repeated to obtain LOs sufficiently.

\subsection{Determination of Physical Properties of LOs}

The physical properties of LOs obtained were determined according to standard parameter of the previous published data [24], including density, refractive index, acid number, and solubility in alcohol.

\subsection{Microencapsulation with Various Weights of LOs}

Microencapsulation procedure was modification of the two established methods [16, 19]. The amount of core material (LOs) addition was varied from $3.0 ; 3.5 ; 4.0 ; 4.5 ;$ to 5.0 grams, while $2 \%(\mathrm{w} / \mathrm{v}$ ) of shell mixture of gelatine and alginate (3.5:1) were dissolved in distilled water. $0.8 \mathrm{~g}$ of tween 80 and $0.18 \mathrm{~g}$ of calcium chloride were employed as emulsifier and cross linker respectively. Firstly, the aqueous solution of gelatine was stirred at $60 \pm 1^{\circ} \mathrm{C}$ and speed of $600 \mathrm{rpm}$. Certain weight of LOs was added dropwise to the solution and followed by sodium alginate solution. The mixture was further stirred for $15 \mathrm{~min}$, and the $p \mathrm{H}$ was then adjusted to 3.75 with addition of $2.5 \%$ of glacial acetic acid. Furthermore, the solution was cooled to $5-10^{\circ} \mathrm{C}$ on an ice bath, and then calcium chloride was added slowly. The solution was further stirred for $3-4 \mathrm{~h}$ at $35-40^{\circ} \mathrm{C}$. Upon cooling process at $25^{\circ} \mathrm{C}$, the microcapsules were formed and then filtered. The microcapsules were washed with $3 \times 20 \mathrm{~mL}$ of distilled water and n-hexane, successively and finally dried in the refrigerator.

\subsection{Variation of Stirring Temperature}

The microencapsulation procedure was carried out in the same way as described with the optimal amount of LOs obtained previously. However, the temperature was varied at $35^{\circ} \mathrm{C}, 40^{\circ} \mathrm{C}, 45^{\circ} \mathrm{C}, 50^{\circ} \mathrm{C}$ and $55^{\circ} \mathrm{C}$ upon addition of cross linker.

\subsection{Variation of Stirring Speed}

The stirring speed was varied at 400, 500,600, 700, and $800 \mathrm{rpm}$ upon microencapsulation process of the optimal amount of LOs and stirring temperature obtained previously. 


\subsection{Characterization of Microcapsules}

The microcapsules obtained were characterized based on their particle size and distribution using Beckman Coulter LS 13320 Particle Size Analyzer (PSA) equipped with optical Fraunhofer, morphology using Leica DME microscope and Scanning Electron Microscope (SEM) JEOL JSM-6510, and LOs content using UV-Vis Perkin-Elmer Lambda type 35. The oil content of microcapsule was calculated by regression equation obtained from the standard curve. The oil load and oil content were calculated using Eq. (1) and (2) respectively, while encapsulation efficiency was with Eq. (3).

$$
\begin{aligned}
& \text { Oil Load }(\%)=\mathrm{w} 2 / \mathrm{w} 3 \times 100 \\
& \text { Oil Content }(\%)=\mathrm{w} 1 / \mathrm{w} \times 100 \\
& \text { EE }(\%)=\mathrm{w} 1 / \mathrm{w} 2 \times 100
\end{aligned}
$$

where, $w 1=$ the actual weight of LOs in microcapsules, w2 = the added weight of LOs, w3 = the total weight of polymer including the cross linker agent, $\mathrm{w}=$ the total weight of the microcapsule.

\subsection{Data Collection and Analysis}

The physical properties of $C$. aurantifolia LOs, the properties of LOs microcapsules affected by various weights of LOs, stirring temperatures, and stirring speeds were expressed as mean \pm standard deviation (SD). Analysis of statistical difference of particle diameter (PSA data) among treatments were performed on RStudio [25]. Shapiro-Wilk test was employed to evaluate the normality of data. The nonparametric method of Kruskal-Wallis rank sum test was used to assess significant differences among treatments [26]. If the Kruskal-Wallis rank sum test rejects the null hypothesis then Dunn's test was conducted as the post Hoc test. All statistical analyses were carried out at a confidence level of $95 \%$.

\section{Results and discussions}

\subsection{Preparation of Lime Oils (LOs)}

Preparation of LOs was carried out for $3 \mathrm{~h}$ using the hydrodistillation method to yield $0.5 \%$ of clear yellowish oil with a fresh aroma of lime fragrance. Moreover, the physical properties of LOs were also determined (Table 1). Inclusively, the results were in agreement with the literature data [27].

Table 1. Physical properties of LOs of C. aurantifolia

\begin{tabular}{|c|c|}
\hline Parameter & Lime oil (LOs)* \\
\hline Density (g/mL) & $0.8604 \pm 0.0299$ \\
\hline Refraction index & $1.5236 \pm 0.0420$ \\
\hline Acid number (\%) & $0.5216 \pm 0.0161$ \\
\hline Solubility in 90\% alcohol & $(1: 4.5 \mathrm{~mL}) \pm 0.0$ \\
\hline
\end{tabular}

The chemical composition of the LOs, reported by Wahyudi et al. [28], contained predominantly of d-limonene (39.23\%), $\beta$-pinene (22.82\%), citral (5.63\%), and $\alpha$-terpineol (3.74\%). The limonene content was found below average (32-98\%) among other lime oils, which might be due to many factors such as, plantation geographic, maturity level, genotype, soil type, climate, and type of extraction process $[8,9$, $29,30]$.

\subsection{Microencapsulation}

The LOs microcapsules with various amounts of LOs were produced by employing two biopolymers of gelatine and alginate $2 \%(\mathrm{w} / \mathrm{v})$ as shell materials with fixed ratio of 3.5:1, tween 80 as emulsifier, and calcium chloride as cross linker showed distinctive particle size of microcapsules which ranged from 52 to $178 \mu \mathrm{m}$ in diameter (Figure 1). In particular, the increasing weight of LOs above $3 \mathrm{~g}$ did not enlarge the particle diameter significantly, yet statistical test of differentiation revealed the substantial influences 
of various LOs content toward particle size distribution. In general, the particles diameter, relied on the core size and wall thickness [31], were in agreement with the standard of microcapsules $(0.2-5.000 \mu \mathrm{m})$ [32]. Other essential parameters of the resulted microcapsules such as, microcapsule yield, oil content, oil load, and encapsulation efficiency were also determined (Table 2).

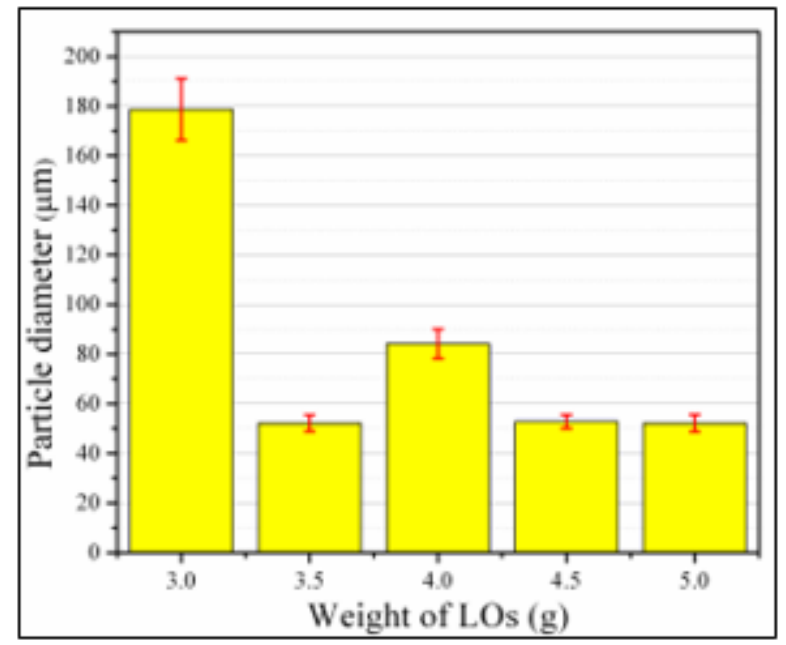

Figure 1. Average size distribution of microcapsules \pm SD at various weights of

LOs. Statistical test of significant differences with $95 \%$ confidence level. Value of $\mathrm{p}<2.2 \times 10^{-16}$ (Kruskal-Wallis test), $\mathrm{p}\left(1.1 \times 10^{-3}-2.9 \times 10^{-66}\right)($ Dunn test) were significantly different among all treatments

Table 2. Effect of various weights of LOs on the properties of microcapsules

\begin{tabular}{|c|c|c|c|c|c|c|c|}
\hline $\begin{array}{l}\text { Weight of } \\
\text { microcapsule } \\
\text { (g) } \mathbf{W}^{*}\end{array}$ & $\begin{array}{c}\text { Weight of } \\
\text { encapsulated oil } \\
\text { (g) W1 }\end{array}$ & $\begin{array}{l}\text { Weight of } \\
\text { added LOs } \\
\text { (g) } \\
\text { W2 }\end{array}$ & $\begin{array}{l}\text { Total } \\
\text { polymer } \\
\text { (g) W3 }\end{array}$ & $\begin{array}{l}\text { Yield } \\
(\%)^{*}\end{array}$ & $\begin{array}{l}\text { Oil } \\
\text { content } \\
(\%)^{*}\end{array}$ & $\begin{array}{c}\text { Oil } \\
\text { load } \\
(\%)\end{array}$ & $\underset{(\%)}{\mathbf{E E}}$ \\
\hline $1.75 \pm 0.17$ & 0.94 & 3.0 & 3.6 & $\begin{array}{c}26.52 \pm \\
2.63 \\
\end{array}$ & $\begin{array}{c}53.41 \pm \\
5.91 \\
\end{array}$ & 83 & $\begin{array}{c}31.20 \pm \\
5.08\end{array}$ \\
\hline $2.23 \pm 0.06$ & 1.23 & 3.5 & 3.6 & $\begin{array}{c}31.46 \pm \\
0.78\end{array}$ & $\begin{array}{c}55.14 \pm \\
3.62\end{array}$ & 97 & $\begin{array}{c}35.17 \pm \\
2.33\end{array}$ \\
\hline $2.40 \pm 0.06$ & 1.37 & 4.0 & 3.6 & $\begin{array}{c}31.54 \pm \\
0.79\end{array}$ & $\begin{array}{c}57.06 \pm \\
5.19\end{array}$ & 111 & $\begin{array}{c}34.24 \pm \\
3.92\end{array}$ \\
\hline $2.56 \pm 0.03$ & 1.49 & 4.5 & 3.6 & $\begin{array}{c}31.65 \pm \\
0.38\end{array}$ & $\begin{array}{c}58.02 \pm \\
5.82\end{array}$ & 125 & $\begin{array}{c}33.02 \pm \\
2.91\end{array}$ \\
\hline $2.73 \pm 0.05$ & 1.65 & 5.0 & 3.6 & $\begin{array}{c}31.71 \pm \\
0.52\end{array}$ & $\begin{array}{c}60.42 \pm \\
10.81 \\
\end{array}$ & 138 & $\begin{array}{c}32.91 \pm \\
5.55\end{array}$ \\
\hline
\end{tabular}

Stirring speed $600 \mathrm{rpm}$, stirring temperature $40{ }^{\circ} \mathrm{C}$, *data were expressed as mean $\pm \operatorname{SD}(n=3)$.

The data (Table 2) showed that the microcapsules yield resulted from various weight of LOs ranged from $26-31 \%$. Increasing of LOs amount more than $3.5 \mathrm{~g}$ (oil load 97\%) did not indicate linier correlation to the yield remarkably. In fact, efficiency of the microcapsules decreased by $1 \%$ per $-0.5 \mathrm{~g}$ of added LOs which might be due to a higher percentage of loss during isolation. Low oil loads allowed the dispersion force by stirrer more effective than at high oil loads, and led to the formation of smaller oil vesicles [33]. In addition, the SEM image (Figure 2) confirmed that morphology of the microcapsules of $3.5 \mathrm{~g}$ of LOs weight more distinctly formed instead of $4.5 \mathrm{~g}$ one, even so the shape of the $4.5 \mathrm{~g}$ one was fairly more rounded and homogeneous with some agglomeration. As anticipated, the agglomeration was due to excessive oil in the system which could cause partial emulsification and alter electrostatic interaction between two biopolymers of gelatine and alginate [13]. Furthermore, un-emulsified oil also caused the microcapsules become sticky and broken [19].

\subsection{Effect of Stirring Temperature on Microencapsulation}

Since formation of microcapsule structure is affected by the cross-linker agent and its stirring temperature [34], the effect of various stirring temperatures upon addition of calcium chloride cross-linker to the properties of microcapsules such as, yield, oil content, oil load, and encapsulation efficiency, was explored (Table 3). Upon microencapsulation process of optimized LOs weight previously obtained (3.5 
g), elevating gradual temperature of stirring by $5^{\circ} \mathrm{C}$ up to $55^{\circ} \mathrm{C}$ tend to decrease yield and efficiency of the encapsulation. In contrast, decreasing the temperature by 5 to $35^{\circ} \mathrm{C}$ increased the yield and efficiency up to $10 \%$. The result was supported by published data [35] which reported the stabilization of the microcapsules system at low temperatures.

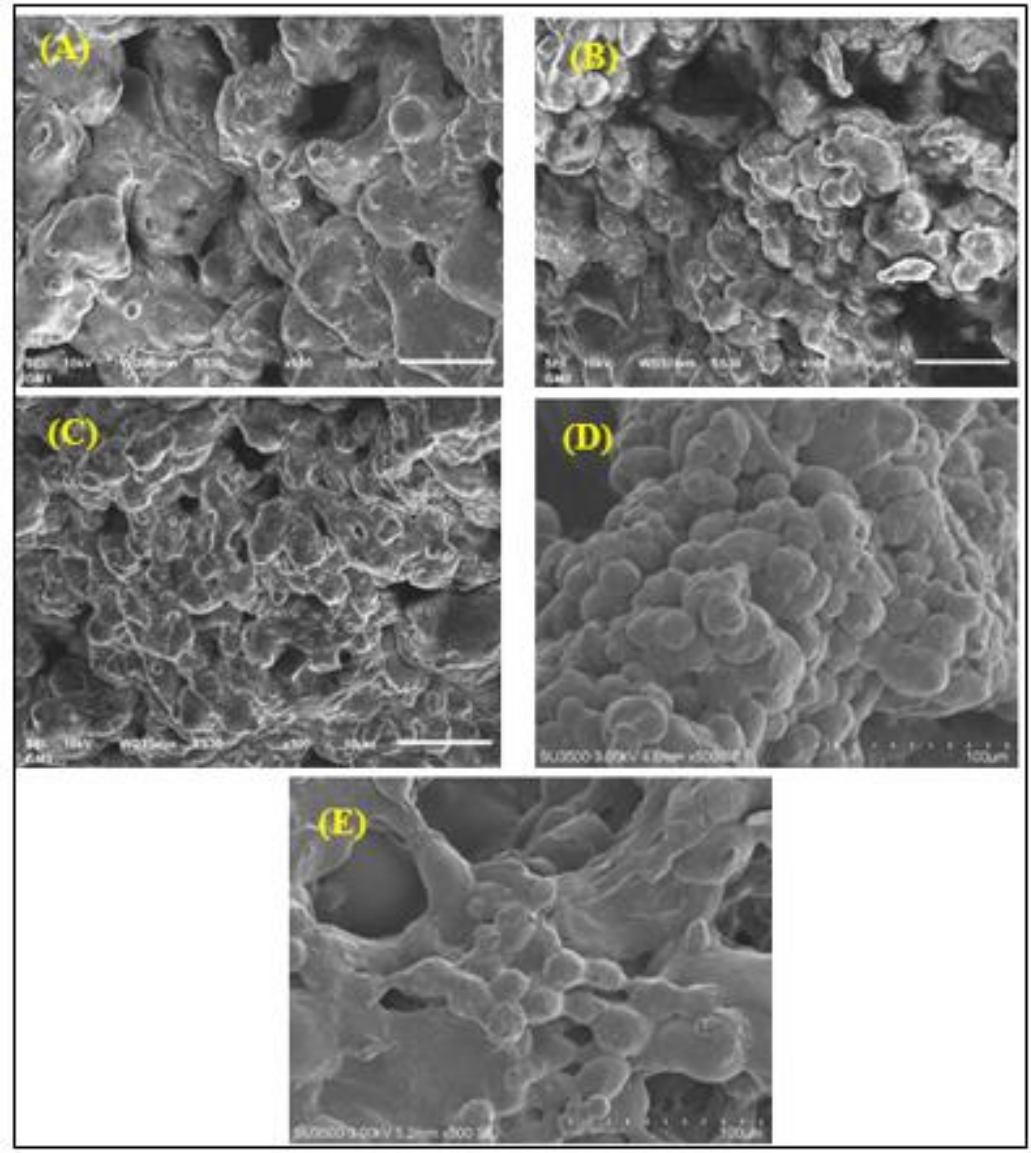

Figure 2. SEM images of microcapsules at various weights of LOs (a) $3.0 \mathrm{~g}$, (b) $3.5 \mathrm{~g}$, (c) $4.0 \mathrm{~g}$, (d) $4.5 \mathrm{~g}$, and (e) $5.0 \mathrm{~g}$

Table 3 Effect of various stirring temperatures on the properties of microcapsules

\begin{tabular}{|c|c|c|c|c|c|c|c|c|}
\hline $\begin{array}{c}\text { T of } \\
\text { stirring } \\
\left({ }^{\circ} \mathrm{C}\right)\end{array}$ & $\begin{array}{l}\text { Weight of } \\
\text { microcapsules } \\
\text { (g) } \mathbf{W}^{*}\end{array}$ & $\begin{array}{c}\text { Weight of } \\
\text { encapsulated } \\
\text { oil (g) W1 }\end{array}$ & $\begin{array}{l}\text { Weight of } \\
\text { added } \\
\text { LOs (g) } \\
\text { W2 }\end{array}$ & $\begin{array}{c}\text { Total } \\
\text { polymer } \\
\text { (g) W3 }\end{array}$ & $\begin{array}{l}\text { Yield } \\
(\%)^{*}\end{array}$ & $\begin{array}{c}\text { Oil } \\
\text { content } \\
(\%) *\end{array}$ & $\begin{array}{c}\text { Oil } \\
\text { load } \\
(\%)\end{array}$ & $\begin{array}{c}\mathbf{E E} \\
(\%)^{*}\end{array}$ \\
\hline 35 & $2.44 \pm 0.11$ & 1.57 & 3.5 & 3.6 & $\begin{array}{c}34.41 \pm \\
1.52 \\
\end{array}$ & $\begin{array}{c}64.74 \pm \\
19.34 \\
\end{array}$ & 97.22 & $\begin{array}{c}45.00 \pm \\
12.95 \\
\end{array}$ \\
\hline 40 & $2.15 \pm 0.11$ & 1.24 & 3.5 & 3.6 & $\begin{array}{c}30.23 \pm \\
1.58\end{array}$ & $\begin{array}{c}62.42 \pm \\
14.77\end{array}$ & 97.22 & $\begin{array}{c}35.30 \pm \\
10.83\end{array}$ \\
\hline 45 & $1.62 \pm 0.22$ & 1.04 & 3.5 & 3.6 & $\begin{array}{c}21.74 \pm \\
3.89\end{array}$ & $\begin{array}{c}63.30 \pm \\
8.19\end{array}$ & 97.22 & $\begin{array}{c}29.68 \pm \\
7.62\end{array}$ \\
\hline 50 & $1.67 \pm 0.07$ & 1.05 & 3.5 & 3.6 & $\begin{array}{c}23.47 \pm \\
1.02\end{array}$ & $\begin{array}{c}62.82 \pm \\
6.60\end{array}$ & 97.22 & $\begin{array}{c}29.90 \pm \\
3.17\end{array}$ \\
\hline 55 & $1.92 \pm 0.10$ & 1.18 & 3.5 & 3.6 & $\begin{array}{c}27.09 \pm \\
1.47\end{array}$ & $\begin{array}{c}61.21 \pm \\
3.95\end{array}$ & 97.22 & $\begin{array}{c}33.62 \pm \\
2.52\end{array}$ \\
\hline
\end{tabular}

Stirring speed of $600 \mathrm{rpm}, *$ data were expressed as mean $\pm \operatorname{SD}(n=3)$

Further analysis of the result obtained upon treatment of various stirring temperature was performed to identify the particle size and its morphology. In spite of the fact that particle diameter of the microcapsules formed at $35^{\circ} \mathrm{C}$ was slightly smaller than at $40^{\circ} \mathrm{C}$ (Figure 3), the morphology of the microcapsules was predominantly more homogeneous and rounder (Figure 4). However, data analysis of 


\section{Revista de Chimie}

significant differences showed that temperature of stirring barely affected distribution of particles diameter.

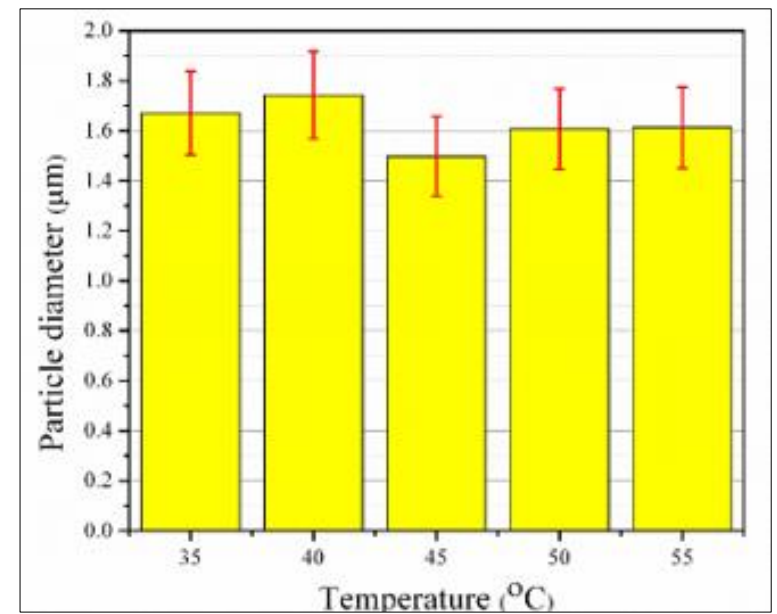

Figure 3. Average of size distribution $\pm \mathrm{SD}$ at various stirring temperatures: $35 ; 40 ; 45 ; 50$; and $55^{\circ} \mathrm{C}$. Statistical test of significant differences with $95 \%$ confidence level. Value of $\mathrm{p}=0.7721$

(Kruskal-Wallis test) was not significantly different among all treatments

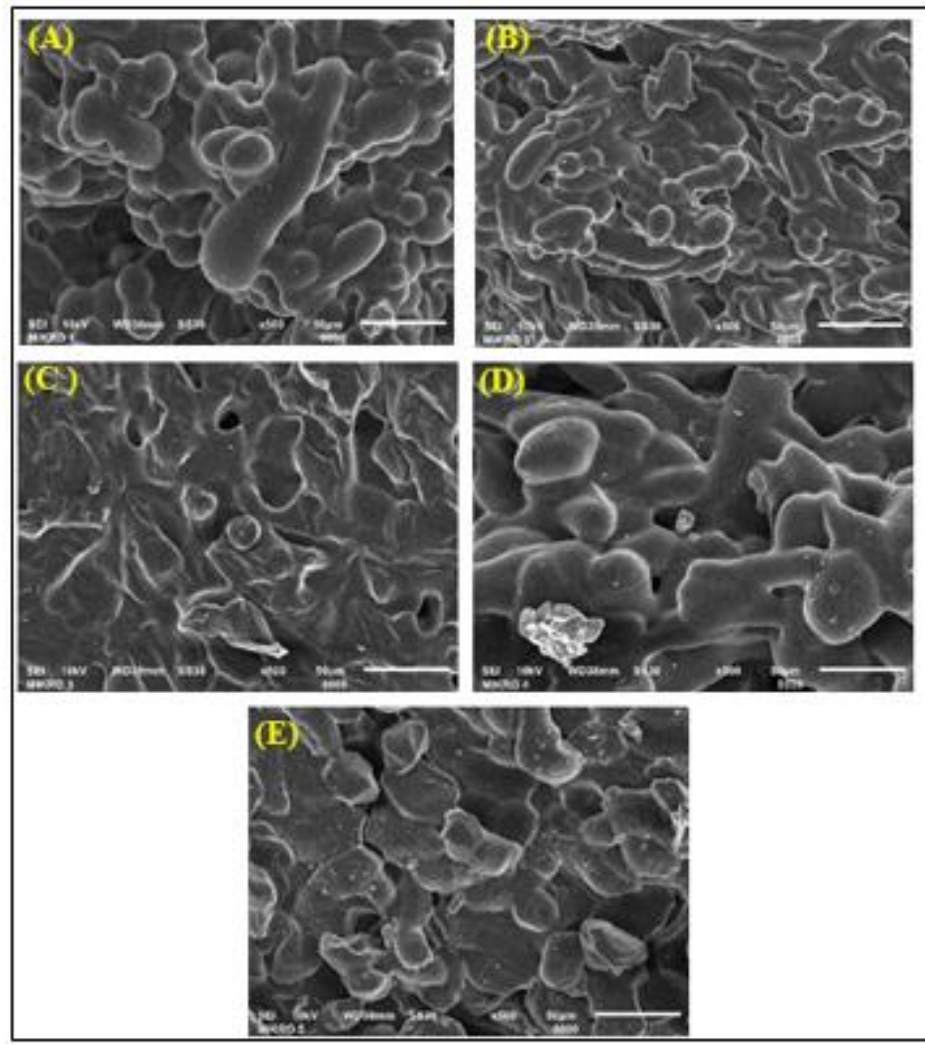

Figure 4. SEM images of microcapsules at various stirring temperatures: (a) $35^{\circ} \mathrm{C}$, (b) $40^{\circ} \mathrm{C}$, (c) $45^{\circ} \mathrm{C}$, (d) $50^{\circ} \mathrm{C}$, and (e) $55^{\circ} \mathrm{C}$ 


\subsection{Effect of Stirring Speed on Microencapsulation}

To improve oil content and efficiency of the microcapsules obtained from the previous optimal condition, more treatment parameter was adjusted. The PSA result (Figure 5) revealed that various speed of stirring produced microcapsules in the range size of $1.40-1.52 \mu \mathrm{m}$ with the yield of $23-30 \%$ (Table 4). In principle, the microcapsule diameters were not substantially influenced by the treatments statistically. Optimal oil content with highest encapsulation efficiency was achieved at $600 \mathrm{rpm}$ stirring speed. Accelerating the speed above $600 \mathrm{rpm}$ just destroyed the encapsulated oil, thus decreased the oil content and efficiency. Based on PSA data (Figure 5) and SEM images (Figure 6), the best microcapsules gave ratio mean/median close to 1 . To end with, the results were supported by previous finding [5, 36], where the speed and length of stirring were not only control the size of microcapsules but also their size distribution.

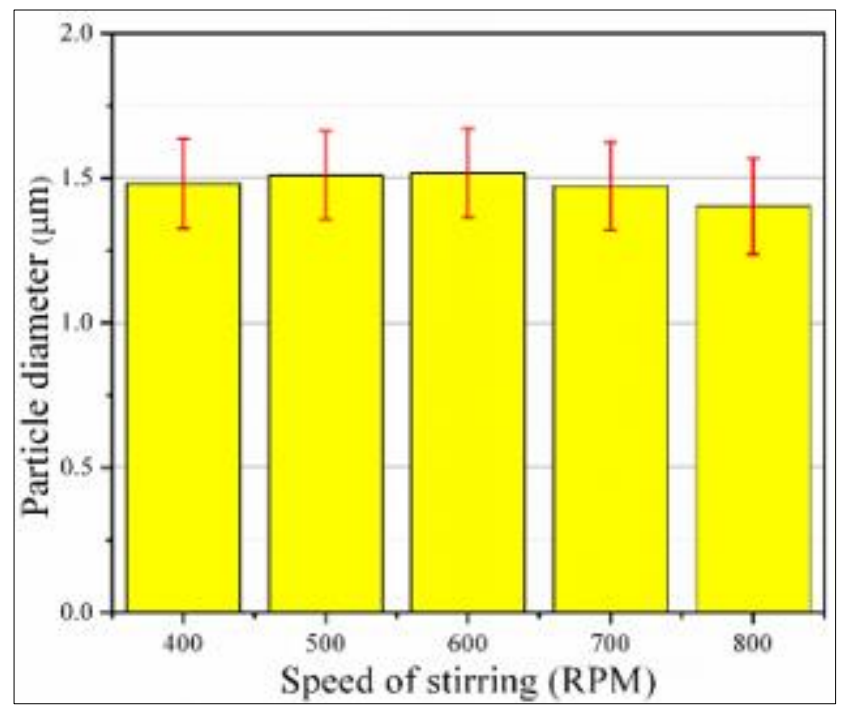

Figure 5. Average of size distribution \pm SD at various stirring speeds 400; 500; 600; 700; and 800 rpm. Statistical test of significant differences with $95 \%$ confidence level. Value of $\mathrm{p}=1$ (Kruskal-Wallis test) was not significantly different among all treatments

Table 4. Effects of various stirring speeds on the properties of microcapsules

\begin{tabular}{|c|c|c|c|c|c|c|c|c|}
\hline $\begin{array}{c}\text { Speed } \\
\text { of } \\
\text { stirring } \\
(\text { rpm })\end{array}$ & $\begin{array}{l}\text { Weight of } \\
\text { microcapsules } \\
\text { (g) } \mathbf{W} *\end{array}$ & $\begin{array}{c}\text { Weight of } \\
\text { encapsulated } \\
\text { oil (g) W1 }\end{array}$ & $\begin{array}{c}\text { Weight of } \\
\text { added } \\
\text { LOs (g) } \\
\text { W2 } \\
\end{array}$ & $\begin{array}{c}\text { Total } \\
\text { polymer } \\
\text { (g) W3 }\end{array}$ & Yield $(\%)^{*}$ & $\begin{array}{c}\text { Oil } \\
\text { content } \\
(\%)^{*}\end{array}$ & $\begin{array}{c}\text { Oil } \\
\text { load } \\
(\%)\end{array}$ & $\begin{array}{c}\mathbf{E E} \\
(\%)^{*}\end{array}$ \\
\hline 400 & $1.74 \pm 0.39$ & 1.10 & 3.5 & 3.6 & $24.51 \pm 5.49$ & $\begin{array}{c}63.49 \pm \\
4.80\end{array}$ & 97.22 & $31.43 \pm 6.80$ \\
\hline 500 & $2.14 \pm 0.79$ & 1.35 & 3.5 & 3.6 & $\begin{array}{c}30.14 \pm \\
11.13\end{array}$ & $\begin{array}{c}63.39 \pm \\
5.56\end{array}$ & 97.22 & $\begin{array}{c}38.63 \pm \\
14.85\end{array}$ \\
\hline 600 & $2.06 \pm 0.47$ & 1.62 & 3.5 & 3.6 & $29.01 \pm 6.62$ & $\begin{array}{c}77.84 \pm \\
6.67\end{array}$ & 97.22 & $\begin{array}{c}46.38 \pm \\
14.04\end{array}$ \\
\hline 700 & $1.85 \pm 0.21$ & 1.36 & 3.5 & 3.6 & $26.06 \pm 2.89$ & $\begin{array}{c}72.75 \pm \\
8.14 \\
\end{array}$ & 97.22 & $38.76 \pm 8.34$ \\
\hline 800 & $1.66 \pm 0.19$ & 0.79 & 3.5 & 3.6 & $23.33 \pm 2.64$ & $\begin{array}{c}46.40 \pm \\
7.06\end{array}$ & 97.22 & $22.48 \pm 1.01$ \\
\hline
\end{tabular}

Stirring temperature was $35^{\circ} \mathrm{C}$, *data were expressed as mean $\pm \operatorname{SD}(n=3)$ 


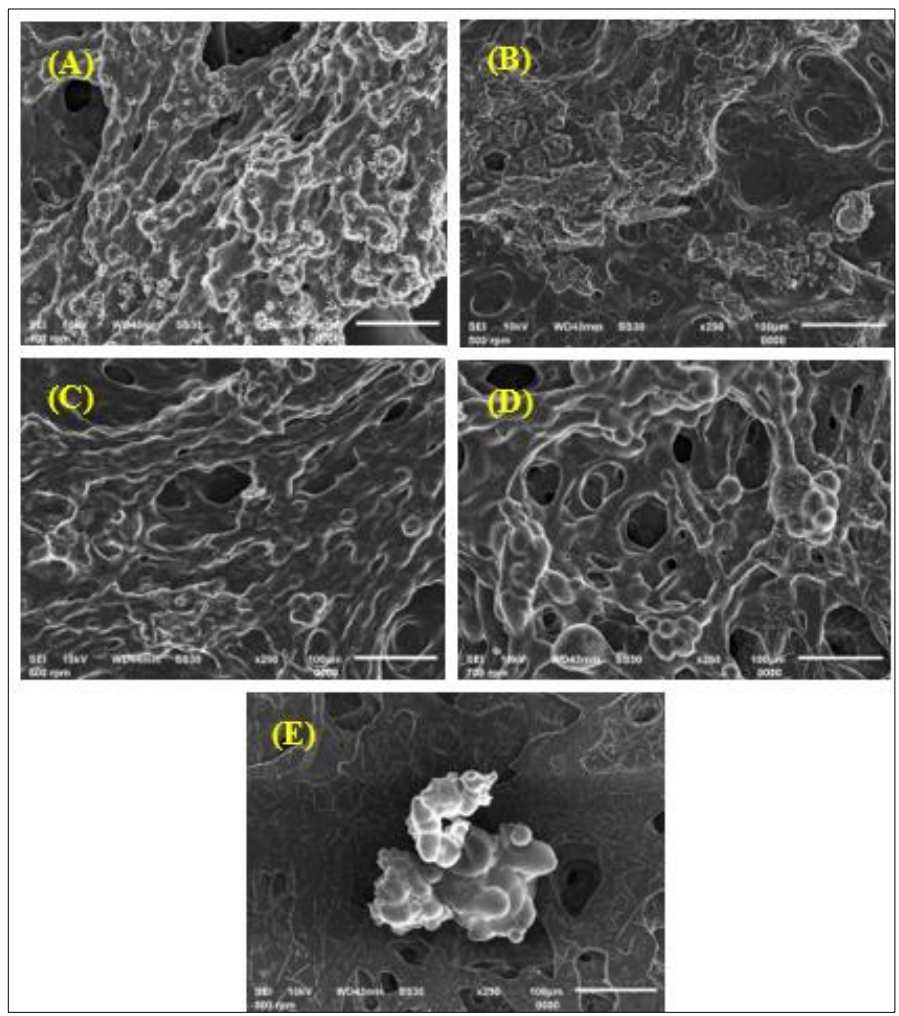

Figure 6. SEM images of microcapsules at various stirring speeds: (a) $400 \mathrm{rpm}$; (b) $500 \mathrm{rpm}$; (c) $600 \mathrm{rpm}$; (d) $700 \mathrm{rpm}$; and (e) $800 \mathrm{rpm}$

\section{Conclusions}

The Lime Oils microcapsules were successfully prepared and characterized at optimum condition of ratio core/shell of 0.49 , speed and temperature of stirring of $600 \mathrm{rpm}$ and $35^{\circ} \mathrm{C}$ respectively, with efficiency of $46 \%$ and oil content of $78 \%$. Physical properties of the microcapsules such as, yield, oil content, encapsulation efficiency, particle size distribution, and morphology were substantially improved. Consequently, it could be more extensively applied for daily need of live, including by incorporation onto functional cotton fabrics or cosmetics, thus enhance their added values economically.

Acknowledgments: The authors thank to the Rector of Universitas Padjadjaran for the facilities provided, KEMENRISTEKDIKTI who provided research fund (PDUPT No.2834/UN6.D/LT/2019), The Center for Textiles as research collaborators and Ari Hardianto, PhD. for data analysis.

\section{References}

1.MAYYA, K.S., BHATTACHARYYA, A., AND ARGILLIER, J.F. Microencapsulation by complex coacervation: influence of surfactant, Polym. Int., 52, 2003, 644-647. doi: 10.1002/pi.1125

2.MARTINS, I. M., BARREIRO, M.F., COELHO, M., AND RODRIGUES, A.E., Microencpsulation of essential oils with biodegradable polymeric carriers for cosmetic application, Chem. Eng. J., 245, 2014, 191-200. doi: 10.1016/j.cej.2014.02.024

3.MIRABEDINI, S.M, DUTIL, I., FARNOOD R.R., Preparation and characterization of ethyl cellulosebased core-shell microcapsules containing plant oils, Colloids Surf. A Physicochem. Eng. Asp., 394, 2012, 74- 84. doi: 10.1016/j.colsurfa.2011.11.028

4.PAULO, F., SANTOS, L., Design of experiments for microencapsulation applications: a review, Mater. Sci. Eng. C, 77, 2017, 1327-1340. doi: 10.1016/j.msec.2017.03.219 
5.ROZENBLAT, J., MAGDASSI, S., GARTI, N., Effect of electrolytes, stirring and surfactants in the coacervation and microencapsulation processes in presence of gelatin, J. Microencapsul., 6 (4), 1989, 515-526. doi: 10.3109/02652048909031171

6.LEMOS Y.P, MARFIL, P.H.M., NICOLETTI, V.R., Particle size characteristics of buriti oil microcapsules produced by gelatine-sodium alginate complex coacervation: effect of stirring speed, Int. J. Food Prop., 20, 2017, 1438-1447. doi: 10.1080/10942912.2017.1349139

7.LIXIA WANG, SHIWEI YANG, JINLI CAO, SHAOHUA ZHAO, AND WUWEI WANG, Microencapsulation of ginger volatile oil based on gelatine/sodium alginate polyelectrolyte complex, Chem. Pharm. Bull., 64, 2016, 21-26. doi: 10.1248/cpb.c15-00571

8.DARJAZI, B.B., The effect of geographical location on mexican lime (Citrus aurantifolia) peel components, Int. J. Agric. Innov. Res., 3(1), 2014, 2319-1473.

9.MAHATO, N., SHARMA, K., KOTESWARARAO, R., SINHA, M., EKRAJ BARAL, E., MOO HWAN CHO. Citrus essential oils: extraction, authentication and application in food preservation, Crit. Rev. Food Sci. Nutr., 59 (4), 2019, 611-625. doi: 10.1080/10408398.2017.1384716

10.ENEJOH, O.S., OGUNYEMI, I.O., BALA, M.S., ORUENE, I.S., SULEIMAN, M.M., AMBALI, S.F., Ethnomedical importance of Citrus aurantifolia (Christm) Swingle, J. Pharm. Innov., 4 (8), 2015, 01-06.

11.COSTA R., BISIGNANOA, C., FILOCAMOA, A., GRASSOA, E., OCCHIUTOA, F., \& SPADARO, F., Antimicrobial activity and chemical composition of Citrus aurantifolia (Christm.) Swingle essential oil from Italian organic crops, J. Essent. Oil Res., 26 (6), 2014, 400-408. doi: 10.1080/10412905.2014.964428

12.SARMA, R., ADHIKARI, K., MAHANTA, S., KHANIKOR, B., Insecticidal activities of Citrus aurantifolia essential oil against Aedes aegypti (Diptera: Culicidae), Toxicol. Rep., 6, 2019, 1091-1096. doi: 10.1016/j.toxrep.2019.10.009

13.XIAO JUN-XIA, YU HAI-YAN, YANG JIAN, Microencapsulation of sweet orange oil by complex coacervation with soybean protein isolate/gum Arabic, Food Chem., 125, 2011, 1267-1272. doi: 10.1016/j.foodchem.2010.10.063

14.MARTINS, E., PONCELET, D., RODRIGUES, R. C., RENARD, D., Oil encapsulation techniques using alginate as encapsulating agent: applications and drawbacks, J. Microencapsul., 34 (8), 2017,754 771. doi: 10.1080/02652048.2017.1403495

15.ALVIM, I.D., GROSSO, C.R.F., Microparticles obtained by complex coacervation: influence of the type of reticulation and the drying process on the release of the core material, Ciênc. Tecnol. Aliment., 30 (4), 2010, 1069-1076. doi: 10.1590/S0101-20612010000400036

16.AlOYS, H., KORMA, S.A., ALICE, T.M., CHANTAL, N., ALI, A.H., ABED, S.M., ILDEPHONSE, H., Methods, techniques, benefits, and applications - a review, J. Am. Food Sci. Nut. Res., 3 (6), 2016, 188-192.

17.AZIZ, F.R.A., JAI, J., RASIAN, R., SUBUKI, I., Microencapsulation of citronella oil complex coacervation using chitosan-gelatine (b) system: operating design, preparation, and characterization, MATEC Web Conf., 69, 2016, 8. doi: 10.1051/matecconf/20166904002

18.DIE DONG, ZHENGLIANG QI, YUFEI HUA, YEMING CHEN, XIANGZHEN KONG, AND CAIMENG ZHANG, Microencapsulation of flaxseed oil by soya proteins-gum arabic complex coacervation, Int. J. Food Sci. Technol., 50, 2015, 1785-1791. doi: 10.1111/ijfs.12812

19.DEVI, N., HAZARIKA, D., DEKA, C., \& KAKATI, D.K., Study of complex coacervation of gelatine and sodium alginate for microencapsulation of olive oil, J. Macromol. Sci., Pure Appl. Chem., 49, 2012, 936-945. doi: 10.1080/10601325.2012.722854

20.SHINDE, U., NAGARSENKER, M. Microencapsulation of eugenol by gelatine-sodium alginate complex coacervation, Indian J. Pharm. Sci., 73 (3), 2011, 311-315. doi: 10.4103/0250-474X.93524

21.ADAMIEC J, BOROMPICHAICHARTKUL C, SRZEDNICKI G, PANKET W, PIRIYAPUNSAKUL S, ZHAO J. Microencapsulation of Kaffir Lime Oil and Its Functional Properties. Dry. Technol., 30 (9), 2012, 914-920. doi: 10.1080/07373937.2012.666777 
22. KUMARI P, ROSE NM, SINGH SSJ. Microencapsulation of lime essential oil for fragrant textiles. Ann. Agri Bio Res., 20, 2015, 152-157.

23.WIJESIRIGUNAWARDANA PB, PERERA BGK. Development of a Cotton Smart Textile with Medicinal Properties Using Lime Oil Microcapsules. Acta Chim. Slov., 65, 2018, 150-159.

doi: 10.17344/acsi.2017.3727

24.JULAEHA, E., NUGERAHA, R., NURZAMAN, M., KURNIA, D., WAHYUDI, T., ROSANDI, Y. Characterization of ethyl cellulose (ec) microcapsules for lime oil encapsulation, J. Phys. Conf. Ser., 1080, 2018, 1-5. doi: 10.1088/1742-6596/1080/1/012038

25.RSTUDIO TEAM, RStudio: Integrated Development Environment for R, Rstudio, 2020, PBC, Boston, MA. Available online: http://www.rstudio.com/ $\left(10^{\text {th }}\right.$ of November 2020).

26. MILLER, J.N.; MILLER, J.C. Statistics and Chemometrics for Analytical Chemistry, Sixth edition, Pearson Education Limited, Essex, 2010, ISBN 9780273730422.

27.AL-AAMRI M.S., AL-ABOUSI, N.M., AL-JABRI, S.S., ALAM, T., \& KHAN, S.A., Chemical composition and in-vitro antioxidant and antimicrobial activity of the essential oil of Citrus aurantifolia L. leaves grown in eastern Oman, J. Taibah Univ. Medical Sci., 13 (2), 2018, 108-112.

doi: 10.1016/j.jtumed.2017.12.002

28.WAHYUDI, T., A. S. MULYAWAN, C. KASIPAH, U. PRAYUDIE, E. JULAEHA., Pembuatan mikrokapsul minyak jeruk (Citrus aurantifolia) untuk aplikasi pada penyempurnaan tekstil, Arena Tekstil, 32 (1), 2017, 1-8. doi: 10.31266/at.v32i1.2661

29.PALAZZOLO, E., LAUDICINA, V.A., GERMANA, M.A., Current and potential use of Citrus essential oils, Curr. Org. Chem., 17, 2013, 3042-3049. doi: 10.2174/13852728113179990122

30.LIN, Y., CHUANG, C., CHEN, H., AND YANG, K., Lime (Citrus aurantifolia (Christm.) Swingle) essential oils: volatile compounds, antioxidant capacity, and hypolipidemic effect, Foods, 8 (398), 2019, 1-11. doi: 10.3390/foods 8090398

31.LECLERCQ, S., HARLANDER, K.R., \& REINECCIUS, G.A., Formation and characterization of microcapsules by complex coacervation with liquid or solid aroma cores, Flavour Fragr. J., 24, 2008, 17-24. doi: 10.1002/ffj.1911

32.SILVA, P.T., FRIES, L.L.M., MENEZES, C.R., HOLKEM, A.T., SCHWAN, C.L., WIGMANN, É.F., BASTOS, J.O., SILVA, C.B., Microencapsulation: concepts, mechanisms, methods and some applications in food technology, Ciênc. Rural, 44 (7), 2014, 1304-1311.

doi: 10.1590/0103-8478cr20130971

33.MAJI, T.K., BARUAH, I., DUBE, S., HUSSAIN, M.R., Microencapsulation of Zanthoxylum limonella oil (ZLO) in glutaraldehyde crosslinked gelatine for mosquito repellent application, Bioresour. Technol., 98, 2007, 840-844. doi: 10.1016/j.biortech.2006.03.005

34.SOLOMON, B., F. F. SAHLE, T. GEBRE-MARIAM, K. ASRES, R. H. H. NEUBERT., Microencapsulation of citronella oil for mosquito-repellent application: Formulation and in vitro permeation studies, Eur. J. Pharm. Biopharm. 80, 2012, 61-66. doi: 10.1016/j.ejpb.2011.08.003

35.SCHMITT, C., TURGEON, S.L., Protein/polysaccharide complex and coacervates in food systems, Adv. Colloid Interface Sci., 167, 2011, 63-70. doi: 10.1016/j.cis.2010.10.001

36.TIMILSENA, Y.P., AKANBI, T.O., KHALID, N., ADHIKARI, B., \& BARROW, C.J., Complex coacervation: principles, mechanisms and applications in microencapsulation, Int. J. Biol. Macromol., 121, 2018, 1276-1286. doi: 10.1016/j.ijbiomac.2018.10.144

Manuscript received: 22.09 .2020 